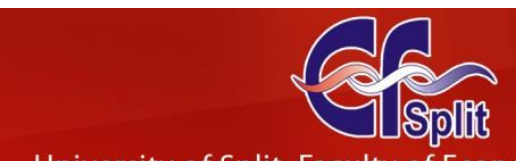

University of Split, Faculty of Economics announces

11th International Conference

Challenges of Europe:

Growth, competitiveness and inequality

Under the auspices of the President of the Republic of Croatia
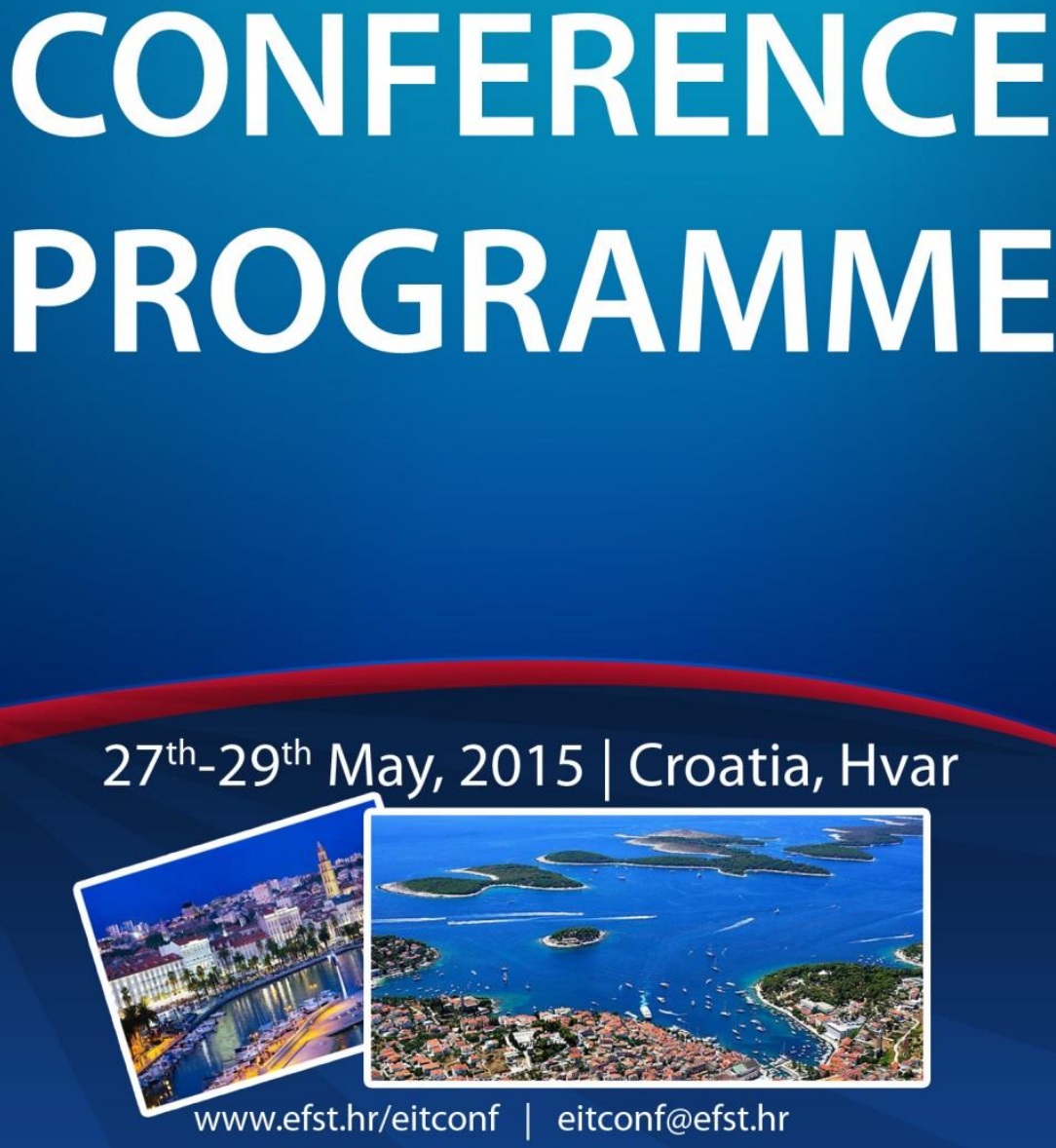


\section{Challenges of Europe:}

Growth, Competitiveness and Inequality

Sponsors and Contributors of the $\mathbf{1 1}^{\text {th }}$ International Conference

Challenges of Europe: Growth, Competitiveness and Inequality

\section{AGROKOR}
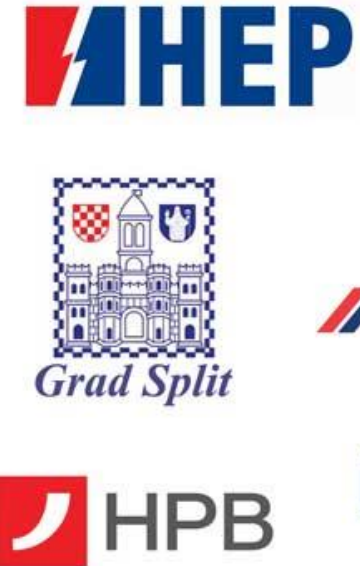

HRVATSKA POŚTANSKA BANKA

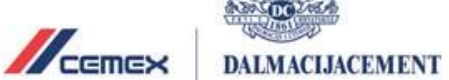

\section{KONĞAR GRUPA}

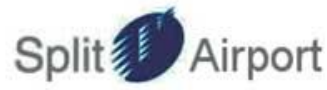

GRADIMO USPJEH ZAJEDNO

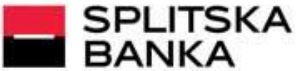

SOCIETE GENERALE CROUP

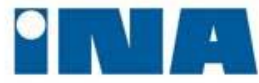

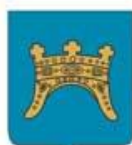

Splitsko dalmatinska županija

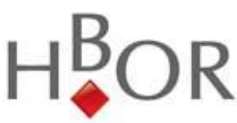

OQNAF $\boldsymbol{F}_{d . d}$

- Telekom

\section{ERTEDMET ALURAIAA}

MINISTARSTVO ZNANOST

OBRAZOVANJA I SPORTA

Ministry of Science, Education

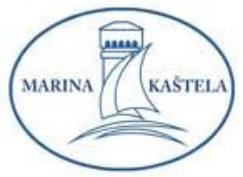

L MINPO

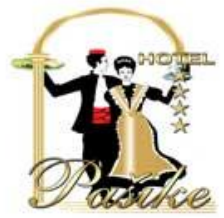




\section{Challenges of Europe:}

\section{Growth, Competitiveness and Inequality}

\section{CONFERENCE SCHEDULE}

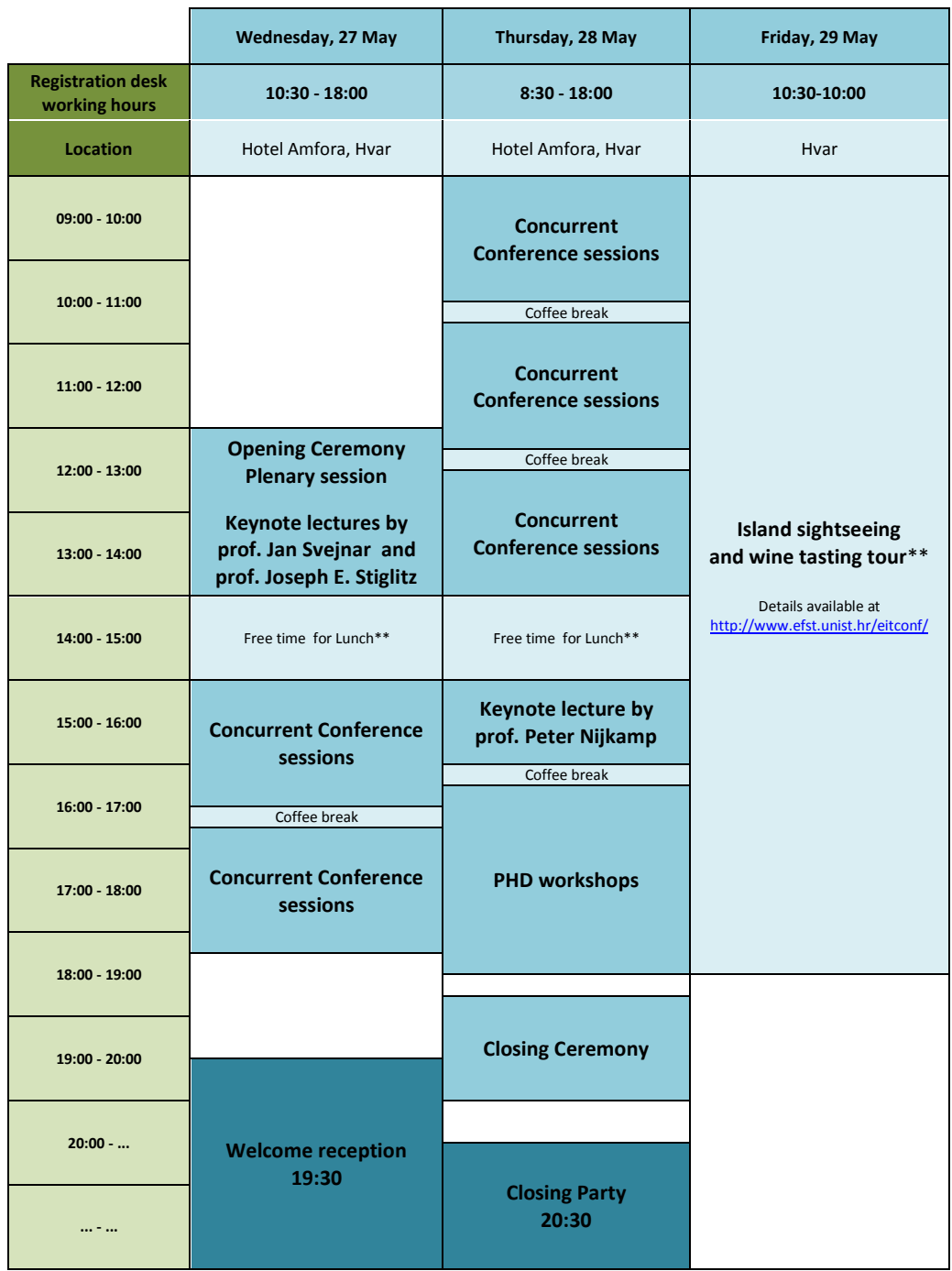

** Not included in registration fee 


\section{Challenges of Europe: Growth, Competitiveness and Inequality}

\section{ACADEMIC PROGRAMME}

\section{OPENING PLENARY SESSION}

(Terrace ballroom)

At the opening plenary session on Wednesday, May 27th (12:00-14:00) our distinguished keynote speakers will give lectures as follows:

Jan Svejnar

Columbia University; School of International and Public Affairs

"Do Billionaires Help or Hurt Economic Growth?"

\section{Joseph E. Stiglitz}

the Nobel laureate in economics 2001

Columbia Business School; the Graduate School of Arts and Sciences (Department of Economics); the School of International and Public Affairs

"The Euro, the European Crisis and Inequality "

\section{KEYNOTE LECTURE}

(Terrace ballroom)

Third keynote lecture will be given on Thursday, May 28th (15:00-16:00) by our distinguished keynote speaker:

\section{Peter Nijkamp}

Free University, The Netherlands

"Cultural Hysteresis, Entrepreneurship and Economic Crisis - Inertia and Resilience after Economic Shocks"

\section{CLOSING CEREMONY}

(Terrace ballroom)

Conference will be closed on Thursday, May 28th (18:45) 


\section{Challenges of Europe: \\ Growth, Competitiveness and Inequality}

Wednesday, 15:00 - 16:30

Macroeconomic stability I

(Grand ballroom 1)

\section{Chair: $\quad$ Lubomir Lizal (Czech Republic)}

1. Lizal, Lubomir; Schwarz, Jiri: FOREIGN EXCHANGE INTERVENTIONS AS AN (UN)CONVENTIONAL MONETARY POLICY TOOL

2. Slobodyan, Sergey; Christev, Atanas: WELFARE LOSSES AND FAST CONVERGENCE OF ADAPTIVE LEARNING

3. Davcev, Ljupco; Hourvouliades, Nikolas: IMPACT OF INTEREST RATE AND INFLATION ON GDP IN FYROM, BULGARIA AND ROMANIA

4. Malenica, Ante; Nadoveza, Ozana; Fučkar, Karla; Bukvić, Vedran: ENDOGENOUS DEFAULT - WHY AND WHEN DO COUNTRIES WITH FIXED EXCHANGE RATE REGIMES DECIDE TO DEFAULT?

5. Dautovic, Ernest; Orszhaghova, Lucia ; Schudel, Willem: CONVERGING IN DIVERGENT WAYS: EXPLAINING TRADE INTEGRATION BETWEEN CESEE COUNTRIES AND THE EU-15

\section{Inequality in Europe (Inequality and social challenges)}

(Grand ballroom 2)

\section{Chair: $\quad$ Božidar Cerović (Serbia)}

1. Bejaković, Predrag; Mrnjavac, Željko: THE ROLE OF THE SOCIAL SECURITY SYSTEM IN REDUCING INCOME INEQUALITY: THE CASE OF THE REPUBLIC OF CROATIA

2. Zulfiu Alili, Merita: AN EMPIRICAL INVESTIGATION OF THE ROLE OF FDI ON WAGE INEQUALITY IN TRANSITION ECONOMIES

3. Mrnjavac, Željko; Blažević, Sanja: DESIGNING ACTIVE LABOUR MARKET POLICY

4. Odobaša, Rajko; Banjari, Ines: THE IMPACT OF AUSTERITY MEASURES ON HEALTH AND HEALTH CARE OF THE POPULATION IN THE EU COUNTRIES AFFECTED BY THE ECONOMIC CRISIS

5. Tuđa, Dora; Bićanić, Ivo: WAGE INEQUALITY IN CROATIA DURING BOOM AND BUST (2000-2014)

6. Costa, Carlos; Bakas, Fiona; Costa, Rui; Breda, Zelia; Durão, Marília; Pinho, Isabel: ' 50 SHADES OF GENDER' WITHIN PORTUGUESE TOURISM INNOVATION, INTERNATIONALIZATION AND NETWORKS

\section{Regional and urban policy, planning and governance (Cities and regions)}

(Grand ballroom 3)

\section{Chair: $\quad$ Karima Kourtit (Netherlands)}

1. Pontarollo, Nicola: the IMPACt Of StRuCtURAL FUndS ON EUROPEAN REGIONS' GROWTH: A SEMIPARAMETRIC SPATIAL FILTERING APPROACH

2. Maleković, Sanja; Puljiz, Jakša; Keser, Ivana: NEW CHALLENGES FOR URBAN GOVERNANCE - CAN WE LEARN FROM EACH OTHER?

3. Drvenkar, Nataša; Marošević, Katarina; Mezulić, Petra: LEARNING REGIONS - REGIONAL ECONOMIC TRANSFORMATION

4. Kancs, $d$ Artis: MACROECONOMIC MODELLING OF R\&D AND INNOVATION POLICIES: AN APPLICATION OF RHOMOLO AND QUEST

5. Obrecht, Matevz; Potrc, Tajda: GREen ZONES IN SELECTED EU CITIES

6. Filipić, Petar: ECONOMIC EFFECTS OF THE CAPITAL CITY 


\section{Challenges of Europe: Growth, Competitiveness and Inequality}

\section{Management \\ (Levanat i Široko)}

\section{Chair: $\quad$ Nikša Alfirević (Croatia)}

1. Madzar, Danijela; Ostojic Mihic, Andrijana; Dulčić, Želimir: APPLICATION OF KNOWLEDGE MANAGEMENT - SMALL AND MEDIUM ENTERPRISES IN FEDERATION OF BOSNIA AND HERZEGOVINA

2. Sitar, Aleša Saša; Pahor, Marko; Škerlavaj, Miha: DIfFERENT STRUCTURE, DIFFERENT LEARNING: THE INFLUENCE OF ORGANIZATIONAL STRUCTURE ON LEARNING BEHAVIOR AT WORK

3. Barbic, Frano; Barbic, Matea; Barbic, Neven: COORDINATION MECHANISMS IN CONTRACTUAL MULTIPARTNER ALLIANCES: A CASE STUDY IN BIOTECH INDUSTRY

4. Savič, Nenad; Rejc Buhovac, Adriana; Ograjenšek, Irena: SUCCESSFUL BUSINESS MODEL TRANSFORMATION: COEXISTENCE OF OLD AND NEW VERSUS THE SPEED OF CHANGE

5. Lovrinović, Josip: ERP - TODAY AND TOMORROW

\section{Industrial and competitiveness policy \\ (Bura i Jugo)}

\section{Chair: $\quad$ Iraj Hashi (UK)}

1. Hashi, Iraj; Hashani, Alban; Lowitzsch, Jens: EMPLOYEE FINANCIAL PARTICIPATION AND FIRM PERFORMANCE IN EU MEMBER STATES: NEW EVIDENCE BASED ON EUROPEAN COMPANY SURVEYS

2. Kocenda, Evzen; Hanousek, Jan; Shamshur, Anastasiya: CORPORATE EFFICIENCY IN EUROPE

3. Domadenik, Polona; Koman, Matjaž; Prašnikar, Janez: tHE EFFECT OF STATE AID ALLOCATION ON PRODUCTIVITY OF SLOVENE FIRMS

4. Stöllinger, Roman: GLOBAL VALUE CHAINS AND STRUCTURAL CHANGE

5. Vlahinić, Nela; Prša, Vedran: ECONOMIC EFFECTS OF ELECTRICITY SECTOR REFORMS: THE CASE OF SOUTHEAST EUROPEAN COUNTRIES

6. Kovac, Dejan; Vukovic, Vuk; Kleut, Nikola: HOW DO FIRMS RESPOND TO ANTICIPATED SHOCKS? DURATION ANALYSIS OF CROATIAN COMPANIES THROUGHOUT THE CRISIS

\section{Wednesday, 16:45 - 18:15}

\section{Macroeconomic stability II}

(Grand ballroom 1)

\section{Chair: Dražen Derado (Croatia)}

1. Mihelja Žaja, Maja; Habek, David; Sović Kržić, Ana: BUDGETARY REFORMS IN EUROPEAN ECONOMIES

2. Voica, Marian Catalin: THE RETURN AND EFFICIENCY OF FOREIGN OWNED VERSUS DOMESTIC OWNED COMPANIES - ROMANIA STUDY CASE

3. Šimović, Hrvoje; Blažić, Helena; Štambuk, Ana: INCOME VS. CONSUMPTION-BASED CONCEPT OF DIRECT TAXATION: ETERNAL DEBATE IN CROATIA

4. Mladineo, Luka; Bubic, Jasenka; Šušak, Toni: VAT RATE CHANGE AND ITS IMPACT ON LIQUIDITY

5. Karalić, Amir; Džakula, Miro: OPTIMAL RATE OF VAT AS DETERMINANT OF ECONOMIC EFFICACY 


\section{Challenges of Europe: Growth, Competitiveness and Inequality}

\section{Management \\ (Grand ballroom 2)}

\section{Chair: $\quad$ Nikša Alfirević (Croatia)}

1. Ljubica, Jasenko; Dulčić, Želimir; Ehnert, Ina: INFLUENCE OF EXPATRIATE CROSS-CULTURAL COMPETENCIES TO THE ORGANISATIONAL INNOVATIVENESS OF THE MNC'S SUBSIDIARIES - THE CASE OF CROATIA

2. Alfirević, Nikša; Talaja, Anita; Pavičić, Jurica: MARKET ORIENTATION AND RESOURCE-BASED VIEW IN EXPLAINING FIRM'S PERFORMANCE AND COMPETITIVE ADVANTAGE

3. Nedelko, Zlatko; Potocan, Vojko: USE OF MANAGEMENT PRACTICES IN ORGANIZATIONS - A COMPARISON BETWEEN CATCHING UP AND WELL-DEVELOPED ECONOMIES

4. Stojcic, Nebojsa; Hashi, Iraj; Orlic, Edvard: CREATIVITY, INNOVATIONS AND PRODUCTIVITY IN UNITED KINGDOM: A FIRM LEVEL ANALYSIS

5. Zupan, Nada; Meglich, Patricia; Mihelič, Katja: THE INFLUENCE OF PERCEIVED WORK-BASED SUPPORT FOR MOTHERS ON WORKPLACE CONDUCT AND PERFORMANCE: A CONCEPTUAL MODEL

\section{Local government and public administration}

(Grand ballroom 3)

\section{Chair: $\quad$ Karima Kourtit (Netherlands)}

1. Ott, Katarina; Bronic, Mihaela; Petrušić, Miroslav; Bezeredi, Slavko: THE LEVEL AND DETERMINANTS OF ONLINE LOCAL BUDGET TRANSPARENCY IN CROATIA

2. Maksimovska Veljanovski, Aleksandra; Stojkov, Aleksandar: fISCAL DECENTRALIZATION AND ETHNIC POLITICS IN MACEDONIA: BUYING TIME?

3. Legčević, Jelena; Dujmović, Jelena: INFLUENCE OF MOTIVATIONAL FACTORS ON THE EFFECTIVENESS OF PUBLIC ADMINISTRATION ACTIONS

4. Pevcin, Primož; Petkovšek, Veronika: Shared MUNICIPAL SERVICES - eXISTING eXPeRIenCes and OPPORTUNITIES FOR SLOVENIA

5. Jurlina Alibegović, Dubravka; Slijepčević, Sunčana: PUBLIC PARTICIPATION IN LOCAL ECONOMIC DEVELOPMENT: THE PERSPECTIVE OF LOCAL COUNCILORS

\section{Inequality and social challenges}

(Levanat i Široko)

\section{Chair: $\quad$ Michael Hughes (UK)}

1. Drosdowski, Thomas; Stöver, Britta; Wolter, Marc Ingo: DOES AGEING CAUSE MORE INEQUALITY IN GERMANY?

2. Pytlikova, Mariola; Filipova, Lenka; Ticha, Michaela: THE ROLE OF BUSINESS CYCLE IN SHAPING INTERNATIONAL MIGRATION

3. Conde, Ana; Xavier Araújo, Maria: COMmUnitY INTEGRATIVE THERAPY: A NEW WAY TO PROMOTE MENTAL HEALTH IN SOCIAL EXCLUSION CONTEXTS

4. Žarković Rakić, Jelena; Ranđelovic, Saša: SOCIAL SECURITY CONTRIBUTIONS REFORM: LABOUR SUPPLY AND INEQUALITY EFFECTS FOR SERBIA

5. Kobus, Martyna; Jakubek, Marcin: YOUTH UNEMPLOYMENT AND MENTAL HEALTH: DOMINANCE APPROACH. EVIDENCE FROM POLAND.

6. de Carvalho, Mateus: AN INVESTIGATION ON SOCIETAL INEQUALITY AVERSION IN WESTERN EUROPE 


\section{Challenges of Europe: Growth, Competitiveness and Inequality}

\section{Regional diversity (Cities and regions)}

(Bura i Jugo)

\section{Chair: Jan van der Borg (Belgium)}

1. Kersan-Škabić, Ines; Tijanić, Lela: REGIONAL ABSORPTION CAPACITY IN THE EUROPEAN UNION

2. Drezgic, Sasa; Grdinic, Maja; Blažić, Helena: efFECTS OF LOCAL GOVERNMENT REVENUE StRucture on INCOME GROWTH AND EMPLOYMENT

3. Costa, Rui; Costa, Carlos; Castro, Eduardo: INVESTMENT DYNAMICS OF TOURISM ENTERPRISES - THE CASE OF PORTUGAL

\section{Thursday, 09:00 - 10:30}

\section{Macroeconomic stability III}

(Grand ballroom 1)

\section{Chair: $\quad$ Michael Keren (Israel)}

1. Cossiga, Giovanni Antonio: THE INSTABILITY OF THE ECONOMY PRE-FINANCIAL CRISIS

2. Vaskova, Miriama; Puskarova, Paula: INCOME INEQUALITY SPILLOVERS AND ECONOMIC GROWTH: EVIDENCE FROM EU COUNTRIES

3. Trifonova, Silvia: ESTIMATING THE IMPACT OF THE GLOBAL FINANCIAL CRISIS ON INDUSTRIES' PERFORMANCE: THE CASE OF BULGARIA

4. Maksimovska Veljanovski, Aleksandra, Neshovska Koseva, Elena: OPEN DOOR TAX POLICY FOR FOREIGN DIRECT INVESTMENTS IN SOUTH EASTERN EUROPE: TAX INCENTIVES FOR ECONOMIC GROWTH

5. Keren, Michael: HARDWARE AND SOFTWARE: ON WHICH ECONOMIC SYSTEMS CAN WE 'RUN' THE STANDARD ECONOMIC MODEL?

\section{Institutions \\ (Grand ballroom 2)}

\section{Chair: $\quad$ Dražen Derado (Croatia)}

1. Stojkov, Aleksandar; Maksimovska Veljanovski, Aleksandra; Warin, Thierry: PUBLIC DEBT MANAGEMENT IN SOUTH EASTERN EUROPE: THE ROLE OF FORMAL INSTITUTIONS

2. Galuscak, Kamil; Babecky, Jan; Lizal, Lubomir: FIRM-LEVEL LABOUR DEMAND: ADJUSTMENT IN NON-CRISIS TIMES AND DURING THE CRISIS

3. Hanousek, Jan; Kochanova, Anna: BRIBERY ENVIRONMENT AND FIRM PERFORMANCE: EVIDENCE FROM CENTRAL AND EASTERN EUROPEAN COUNTRIES

4. Farkas, Beata: MODELS OF CAPITALISM IN THE EUROPEAN UNION AND THEIR COMPETITIVENESS - POST-CRISIS PROSPECTS

5. Goebel, Katarzyna: ACCELERATING THE ENERGY TRANSITION IN THE EU BY THE MEANS OF FINANCIAL PARTICIPATION OF CITIZENS IN RENEWABLE ENERGY PROJECTS - CHOSEN POLITICAL AND ECONOMIC PRECONDITIONS

\section{Entrepreneurship and tourism}

(Grand ballroom 3)

\section{Chair: $\quad$ Iraj Hashi (UK)}

1. Planinc, Saša; Sedmak, Gorazd; Planinc, Tanja; Kociper, Tina: ROLE OF ICT IN RURAL ENTREPRENEURSHIP IN TOURISM: THE EVIDENCE FROM SLOVENIA 


\section{Challenges of Europe: Growth, Competitiveness and Inequality}

2. Queiroz, Françoise; Rastrollo Horrillo, Maria Angeles: CONSTRUCTING INDICATORS FOR TOURIST DESTINATIONS GOVERNANCE: A THEORETICAL FRAMEWORK

3. Križan, Anja; Garbin Praničević, Daniela: WEB ANALYTICS AS SUPPORT TO TOURISM DEVELOPMENT STRATEGY

4. Šerić, Neven; Ljubica, Jasenko; Jerković, Martina: EVALUATION OF THE TOURIST RESORT STRATEGIC MANAGEMENT MODEL IN THE EASTERN ADRIATIC LITTORAL

5. Medaric, Zorana; Šuligoj, Metod; Loncaric, Dina: TOURISM PLANNING IN THE REGION OF ISTRIA: HISTORICAL OVERVIEW AND FUTURE PROSPECTS

6. Voit, Ann-Katrin: DENSITY OF TOURIST ACTIVITY AROUND THE WORLD HERITAGE SITES - HOW DOES THE TOURISTIC CITYSHAPE DEVELOPE CLOSE TO WORLD HERITAGE LANDMARKS IN NORTH AMERICA AND EUROPE?

\section{Gender inequality}

(Levanat i Široko)

\section{Chair: $\quad$ Renata Franc (Croatia)}

1. Gomez Costilla, Patricia; Garcia Prieto, Carmen; Somarriba Arechavala, Noelia; Merino Llorente, Mari Cruz: A STUDY OF THE GENDER WAGE GAP BY LEVEL OF EDUCATION IN SPAIN

2. Merino Llorente, Mari Cruz; Somarriba Arechavala, Noelia; Garcia Prieto, Carmen; Gomez Costilla, Patricia: PART-TIME EMPLOYMENT IN SPAIN. WHAT'S DIFFERENT FOR WOMEN?

3. Koczan, Zsoka: INEQUALITY AND POVERTY IN THE WESTERN BALKANS

4. Suarsana, Denis: INCLUSIVE CAPITALISM IN THE SECOND MACHINE AGE

5. Ramos, Raul; Royuela, Vicente; Castells-Quintana, David: INEQUALITY IN EUROPEAN REGIONS

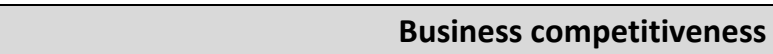

(Bura i Jugo)

\section{Chair: $\quad$ Anthony Simintiras (UK)}

1. Došenović Bonča, Petra; Tajnikar, Maks; Ponikvar, Nina: TYPOLOGY AND CHARACTERISTICS OF GROWING AND FAST GROWING FIRMS: THE CASE OF SLOVENIA IN THE 2007-2012 PERIOD

2. Simintiras, Antonis ; Dwivedi, Yogesh: COST TRANSPARENCY AND PRICE FAIRNESS

3. Pavičić, Jurica; Alfirević, Nikša; Najev Čačija, Ljiljana: THE NONPROFIT MARKETING PROCESS AND FUNDRAISING PERFORMANCE OF HUMANITARIAN ORGANIZATIONS: EMPIRICAL ANALYSIS

4. Gluic, Jasna; Mihanović, Zoran: INTERNATIONAL MARKET ORIENTATION AND STAKEHOLDER MANAGEMENT IN INSTITUTIONS OF CULTURE AND ART IN CROATIA

5. Breznik, Lidija; Lahovnik, Matej: DYNAMIC CAPABILITIES AND COMPETITIVE ADVANTAGE: FINDINGS FROM CASE STUDIES

\section{Thursday, 10:45 - 12:15}

\section{Macroeconomic stability IV}

(Grand ballroom 1)

\section{Chair: $\quad$ Milica Uvalić (Italy)}

1. Marsal, Ales; Kaszab, Lorant; Horvath, Roman: FISCAL POLICY AND THE TERM STRUCTURE OF INTEREST RATES IN A DSGE MODEL

2. Liu, Zixi: DO DEBT AND GROWTH DANCE TOGETHER? A DSGE MODEL OF A SMALL OPEN ECONOMY WITH SOVEREIGN DEBT

3. Svejnar, Jan; Uvalic, Milica: ARE THE WESTERN BALKANS CATCHING UP AFTER A LOST DECADE? 


\section{Challenges of Europe: Growth, Competitiveness and Inequality}

4. Mönnig, Anke; Zika, Gerd: STATUTORY MINIMUM WAGES IN GERMANY - DO THEY ALTER LABOUR DEMAND? A SENSITIVITY ANALYSIS FOR GERMANY

\section{Entrepreneurship}

(Grand ballroom 2)

\section{Chair: $\quad$ Anthony Simintiras (UK)}

1. Pešorda, Lucija; Gregov, Zrinka: OPTIONS to BOOST THE DEVELOPMENT AND THE SUSTAINABILITY OF THE CROATIAN ECONOMY BY JOINING IN COOPERATIVES

2. Crnogaj, Katja; Bradač Hojnik, Barbara: InSTITUTIONAL DETERMINANTS AND ENTREPRENEURIAL ACTION: CROSS-COUNTRY EVIDENCE

3. Sedlan-Kőnig, Ljerka: INTEGRATING SELF-EFFICACY INTO EDUCATION AT ENTREPRENEURIAL UNIVERSITIES

4. Šergo, Zdravko; Ružić, Pavlo: THE MODELING OF THE ENTERPRISE ZONE ALLOCATION IN CROATIA

5. Bilic, Ivana; Markovina, Jerko : PERCEIVED SELF-EFFICACY AND DESIRABILITY OF SELF-EMPLOYMENT ON A SAMPLE OF CROATIAN YOUNG ADULTS

6. Janeska-Iliev, Aleksandra; Debarliev, Stojan: FAMILY BUSINESS CHARACTERISTICS AND DIFFERENCES: SOME INSIGHTS FROM THE DEVELOPING COUNTRIES

\section{Growth and development}

(Grand ballroom 3)

\section{Chair: $\quad$ Alberto Chilosi (Italy)}

1. Alvan-Bozdereli, Arzu; Güler, Betül: INVESTIGATING THE HETEROGENEITY IN PRODUCTION FUNCTION: A CASE STUDY FOR TURKISH MANUFACTURING INDUSTRY

2. Rubínová, Stela; Dhyne, Emmanuel: THE SUPPLIER NETWORK OF EXPORTERS: CONNECTING THE DOTS

3. Djordjevic, Ljubica; Brunnetti, Marianna; Ciciretti, Rocco: tILL MORTGAGE DO US PART: REFINANCING COSTS AND COMPETITION IN THE MORTGAGE MARKET

4. Tovar Reanos, Miguel Angel: FUel fOR INEQUALITY: DISTRIBUTIONAL EFFECTS OF A SUBSIDY TO ELECTRICAL VEHICLES

5. Mihuț, Marius loan: ECONOMIC DOCTRINE OF NIPPONISM. POSSIBLE SOURCE OF INSPIRATION FOR EUROPEAN COUNTRIES AND CHINA

\section{Industrial and competitiveness policy / Infrastructure and transport} (Levanat i Široko)

\section{Chair: $\quad$ Krešimir Žigić (Czech Republic)}

1. Piekkola, Hannu: INTANGIBLE INVESTMENT AND GROWTH IN EUROPE

2. Katičić, Ljiljana; Dulčić, Želimir; Lisjak, Dragutin: CONCEPT OF PHYSICAL ASSET MANAGEMENT

3. Domadenik, Polona; Farcnik, Dasa: GOVERNMENT SUBSIDIES FOR EMPLOYMENT AND LABOUR ADJUSTMET PROCESSES

4. Yevdokimov, Yuri: eCONOMIC EVALUATION OF CLIMATE CHANGE IMPACTS ON ROAD TRANSPORTATION IN ATLANTIC CANADA

5. de Simone, Luisa; Arbolino, Roberta: MEASURING INDUSTRIAL ENVIRONMENTAL SUSTAINABILITY WITH A COMPOSITE INDICATOR: EVIDENCE FROM ITALIAN REGIONS

6. Yaffai, Muna; Dunsch, Sophie; Nolte, Jone; Lowitzsch, Jens: SOCIEDADES LABORALES (WORKER-OWNED COMPANIES) IN SPAIN - A SUCCESSFUL TOOL FOR FIGHTING UNEMPLOYMENT? 


\section{Challenges of Europe: Growth, Competitiveness and Inequality}

\section{Inequality and social challenges}

(Bura i Jugo)

\section{Chair: Branislav Boričić (Serbia)}

1. Dimovski, Vlado ; Penger, Sandra; Grah, Barbara; Jovanovska, Katerina; Peterlin, Judita: THE CHANGING CONTEXT OF HIGHER EDUCATION IN EUROPE

2. Arabadzhieva, Martina; Vutsova, Albena : INNOVATIVE TOOLS SUPPORTING HIGHER EDUCATION DEVELOPMENT. GOOD PRACTICES AND POSSIBLE SOLUTIONS.

3. Kovács, Szilárd; Pusztai, Réka; Sipos, Norbert: eConomist StUdents' MIGRATIONS IN THE hUNGARIAN HIGHER EDUCATION SYSTEM

4. Villani, Salvatore; Ferrara, Luigi; Liotti, Giorgio: HOW IMMIGRATION CAN REDUCE INCOME INEQUALITIES AND MITIGATE ECONOMIC IMBALANCES: THE ITALIAN CASE

5. Svetina Nabergoj, Anja; Pahor, Marko; Adlesic, Renata: IMPLEMENTING FAMILY-FRIENDLY ORGANIZATIONAL PRACTICES: ANALYZING THE MODERATING EFFECTS ON WORK-FAMILY CONFLICT OF EMPLOYEES

6. Filipova, Lenka; Gottvald, Jaromír; Janíková, Lenka: GENDER WAGE GAP IN THE CZECH REPUBLIC: FOCUS ON FAMILY FACTORS, FAMILY-CAREER BALANCE, PREFERENCES AND GENDER IDENTITY FACTORS

\section{Thursday, 12:30 - 14:00}

\section{Macroeconomic stability $\mathbf{V}$ \\ (Grand ballroom 1)}

\section{Chair: $\quad$ Alberto Chilosi (Italy)}

1. Praščević, Aleksandra: OPPORTUNISTIC AND PARTISAN EFFECTS ON FISCAL CONSOLIDATION IN SERBIA

2. Wierus, Kamil; Szczypińska, Agnieszka: PRODUCt MARKET REgULATIONS AND THE FUNCTIONING IN A MONETARY UNION

3. Sattarova, Liliya; Slavutskaya, Anna: EUROVISIONNESS: VISION OF EUROPE AND GDP

4. Cerovic, Bozidar: TRANSITION AND AUSTERITY - HANDICAPPED TWIN POLICIES THE CASE OF WESTERN BALKANS

\section{Finance, banking and accounting}

(Grand ballroom 2)

\section{Chair: $\quad$ Evan Kraft (USA)}

1. Gersl, Adam; Seidler, Jakub: COUNTERCYCLICAL CAPITAL BUfFERS AND EQUILIBRIUM CREDIT LEVEL IN CENTRAL AND EASTERN EUROPEAN COUNTRIES

2. Jurun, Elza; Ratković, Nada ; Matić, Ivana: PERIODIC AVERAGE NATIONAL REFERENCE RATE AS A NEW STANDARD OF FINANCIAL COMPETITIVENESS

3. Buzatu, Cristian: BEHAVIORAL INFLUENCES IN ROMANIAN BANKS LENDING PROCESS

4. Kastrati, Albulenë; Adnett, Nick: THE DETERMINANTS OF EXCESS LIQUIDITY IN EUROPEAN TRANSITION ECONOMIES

5. Čular, Marko; Maretić, Marija: TRANSPARENCY OF AUDIT FIRMS, AUDIT COMMITTEE EFFECTIVENESS AND INTERNAL AUDIT EXISTENCE

6. Zaman Groff, Maja; Salihović, Amela: AUDIT MARKET CONCENTRATION FOR THE SEGMENTS OF LISTED AND NON-LISTED AUDITEES IN SLOVENIA 


\section{Challenges of Europe: Growth, Competitiveness and Inequality}

\section{Macroeconomic stability VI}

(Grand ballroom 3)

\section{Chair: $\quad$ Sergey Slobodyan (Czech Republic)}

1. Yamaguchi, Masao: REAL MINIMUM WAGE HIKE, UNEMPLOYMENT AND DEFLATION

2. Dumicic, Mirna: ACCUMULATION OF SYSTEMIC RISKS AND CONSEQUENCES OF SYSTEMIC SHOCKS - CASE OF CROATIA

3. Magalhaes, Manuela: MULTI-SECTOR GROWTH MODEL WITH TECHNOLOGY DIFFUSION AND NETWORK

\section{Agriculture and fisheries}

(Levanat i Široko)

\section{Chair: Željko Mrnjavac (Croatia)}

1. Bíró, Boróka-Júlia; Bíró, Bíborka-Eszter : TO ALLY OR NOT TO ALLY? APPLICATION OF RURAL DEVELOPMENT MEASURE 142 IN ROMANIA BETWEEN 2007 AND 2013

2. Skarżyńska, Aldona; Augustyńska-Grzymek, Irena; Jabłoński, Konrad : EQUIPMENT AND EFFECTIVENESS OF THE USE OF FIXED ASSETS IN ECONOMICALLY WEAK AND STRONG FARMS IN SELECTED COUNTRIES OF CENTRAL AND EASTERN EUROPE

3. Żekało, Marcin; Augystynska-Grzymek, Irena ; Czułowska, Magdalena ; Skarżyńska, Aldona ; Stalgiene, Aldona: THE VIEW OF DAIRY SECTOR AND THE ECONOMIC SITUATION OF MILK PRODUCERS IN POLAND AND IN LITHUANIA AFTER ACCESSION TO THE EU

4. Tišma, Sanja; Škunca, Ognjen; Boromisa, Ana-Maria; Čermak, Helena: MARINE LITTER MANAGEMENT IN FISHERIES SECTOR IN CROATIA: SOCIAL INNOVATION FOR CIRCULAR ECONOMY

\section{Thursday, 16:15 - 18:45}

\section{PHD workshop I \\ (Grand ballroom 1)}

\section{Chair: $\quad$ Krešimir Žigić (Czech Republic)}

1. Dimperio, Paolo: RISK SHARING TOWARDS THE EUROPEAN FISCAL UNION

2. Lenarčič, Črt: IS THERE A HARROD-BALASSA-SAMUELSON EFFECT PRESENT IN THE DATA? NEW QUARTERLY PANEL DATA EVIDENCE FROM 25 EUROPEAN COUNTRIES

3. Poklepović, Tea; Arnerić, Josip: NEURAL NETWORK STRUCTURE IDENTIFICATION IN MEASUREMENT OF EXPECTED INFLATION

4. Horvatin, Darko: FOREIGN DIRECT INVESTMENT AND ECONOMIC GROWTH: TAKING STOCK OF THE CURRENT STATE OF EMPIRICAL RESEARCH

5. Pruchnik, Kamil: HOW REAL IS THE RISK OF THE CEE ECONOMIES FALLING INTO THE MIDDLE-INCOME TRAP?

6. Sharony, Chen: the WELFARE STATE AND REDISTRIBUTION POLICY - PUBLIC PREFERENCES AND ACTUAL POLICY COMPARATIVE STUDY

7. Catalano, Gabriella: FISCAL POLICIES AND INTEREST RATES IN THE EMU: AN EMPIRICAL ANALYSIS

\section{PHD workshop II}

(Grand ballroom 2)

\section{Chair: $\quad$ Ivan Pavić (Croatia)}

1. Pasca, Lucian: A QUANTUM MECHANICS APPROACH TOWARDS FINANCIAL SYSTEM DYNAMICS MODELLING 


\section{Challenges of Europe: Growth, Competitiveness and Inequality}

2. Mulliqi, Arta: HUMAN CAPITAL AND INTERNATIONAL COMPETITIVENESS: EMPIRICAL EVIDENCE

3. Kummritz, Victor: GLOBAL VALUE CHAINS: BENEFITING THE DOMESTIC ECONOMY

4. Antičić, Nina: INFLUENCE OF PERCEPTION OF VALUE DELIVERY SYSTEM ON CUSTOMER SATISFACTION AND CUSTOMER LOYALTY

5. Loxha, Arberesha: THE IMPACT OF EDUCATION ON POVERTY IN KOSOVO AND ALBANIA

6. Toš Bublić, Tajana: PARADOXAL CAPITAL FLOWS IN EURO AREA 